\title{
Evaluating the Teaching-Learning Process of Brazilian Sign Language as a Second Language in Higher Education
}

\author{
Roberto Cesar Reis da Costa ${ }^{1}$ \\ ${ }^{1}$ Department of Vernacular Language, Institute of Languages and Arts, Federal University of Bahia, Salvador (BA), \\ Brazil \\ Correspondence: Roberto César Reis da Costa, Departamento de Letras Vernáculas, Instituto de Letras, Universidade \\ Federal da Bahia, Salvador, BA, CEP 40170-115, Brasil. E-mail: rcrcosta@ufba.br
}

Received: October 21, 2017

Accepted: November 15, 2017

Online Published: June 13, 2018

doi:10.5430/irhe.v3n2p99

URL: https://doi.org/10.5430/irhe.v3n2p99

\begin{abstract}
The focus of this paper is to propose an evaluation tool to assess the teaching-learning process of Brazilian Sign Language (Libras) to hearing students in Higher Education. The current Brazilian laws dealing with the accessibility of the deaf and the teaching of Libras will be concisely posited and argued, and after that an overview on linguistic aspects of Libras will be highlighted prior to discussing the teaching of this language as a Second Language (L2). Also, it will be discussed briefly the relevance of using strategies to Libras teaching as L2 and then the proposal to evaluate teaching and learning processes of the language at stake will be finally described. As a conclusion, developing tools as well as presenting proposals for the teaching of sign languages might be ways to highlight and discuss pedagogical issues about the teaching of the sign languages. The paper outcomes are useful for scholars and learners who are researching and implementing tools for Libras teaching as L2.
\end{abstract}

Keywords: evaluation, Brazilian Sign Language, higher education, teaching-learning process, L2

\section{Introduction}

The aim of this paper is to present a proposal for evaluating the teaching-learning process in the subjects of Brazilian Sign Language (also known as Libras) to hearing students. Both teaching strategies and the tool used to evaluate have been adopted for optimizing the learning assessment of undergraduate students who are acquiring Libras as a Second Language (L2) in the context of Higher Education.

The forthcoming sections will address the topics which follow: legal aspects about Libras teaching in Higher Education; an overview on linguistic aspects of Libras; the teaching of Libras as L2; the relevance of using strategies to teach Libras as L2; the proposal for evaluating the teaching and learning process of Libras; and, in the closing section, the ending remarks.

\section{The Libras Course in Higher Education: Legal Aspects}

The Law \# 10436 recognized Libras as an "official" language (cf. Brasil, 2002). This Law is also renowned as "Libras Act" or, as Brazilians say, "Lei de Libras". It is necessary to stress that this language has not been established or created from this law onward, taking into account that linguistic studies have already been conducted in Brazil since the 1980s. On linguistic research, it is relevant to state that Ferreira-Brito (1984, 1990a, 1990b, 1995) was one of the first researchers to describe and analyze the Brazilian Sign Language. Linguistic aspects of that language will be presented in the further section, and henceforth the legal viewpoint is about to be posed and analyzed synthetically at the current section.

According to current laws, Libras must be understood as " [...] the way of communicating and expressing, in which the linguistic system based on visual and motors skills, with its own grammatical structure, make up a linguistic system which communicates the ideas and the facts arising from the communities of deaf persons in Brazil." (Brazil's Federal Law \# 10436, art. 1, single paragraph, my translation)

After the approval of this bill, one might think, 'that's a lot because the accessibility of the deaf would be guaranteed'; nonetheless, 'that's not how things work' since the legal recognition of Libras was not enough to solve some queries. In this perspective, both the aforesaid law and the Accessibility Act - Law \# 10098 (cf. Brasil, 2000) have not been enough to install or implement public policies to assure the spread of this language. Law \#10436 is 
made up of five (5) articles, with sole paragraphs in the articles 1 and 4 and without any clauses, items, subparagraphs and sub-items. Because of that fact, this law did not lay down the rules to ensure the linguistic rights for the deaf, between other correlate queries. Such problem was only solved after the approval of a specific decree that is going to be argued in the forthcoming paragraphs.

The Decree \# 5626 supplements the Law \# 10436 and the article 18 of the Law \# 10098. With respect to this article, it is important to quote; "The Government will implement training courses for professional interpreters on writing in Braille, sign language and guide-interpreters to facilitate any kind of direct communication to the person with a sensory impairment and communication disability" (Brazil's Federal Law \# 10098, art. 18, my translation). To avoid deviating from the focus of the topic discussed, it is not significant to get in the middle of the discussion about disabilities right now.

Still on the decree under discussion, the article 3 establishes that; "Libras must be inserted as a mandatory subject into the teacher training courses for exercising the teaching profession in middle and higher education levels, as well as the courses of Speech and Language Therapy, at public and private educational establishments, in the federal teaching system and in the teaching system of the States, the Federal District, and the Towns. Paragraph 1. All licentiateship courses in different fields of knowledge, including the courses from Normal Colleges/Schools which train teachers to work at the levels of Secondary (High-School) and Tertiary (Higher Education) Schools, the Pedagogy Course and the Special Education Course, are regarded as teacher training courses for exercising the teaching profession. Paragraph 2. Libras will be an elective subject for the other courses in Higher and Professional Education from one year after the publication of this bill." (Brazil's Federal Decree \# 5626, my translation)

Ever since then, it has become imperative that Higher Education Institutions, which hold the courses mentioned in the decree, began to offer the subject of Libras in the curriculum of their courses. By stressing the importance of Libras courses in academic spheres, Santos and Campos (2014, p. 240, author's italics) state, "The inclusion of LIBRAS subject in the curriculum of the licentiateship courses defines a new view on deaf individuals by diffusing their language in a privileged environment with the access restricted to a small part of the population; the presence of LIBRAS in the academic community raises its status and demystifies some prejudices."

On one hand, more than regulating and establishing legal provisions in laws and decrees, it is of utmost importance to include this subject in higher education, taking into consideration that universities must play an important role in bringing up the discussion on the history of the deaf, Linguistics of sign languages, the inclusion of the deaf, sign language acquisition, and so forth. On the other hand, and "un/fortunately", the setting of legal documents to implement specific public policies as regards the deaf education is needed.

The decree at stake does not specify the course load and the contents to be approached. The House of Higher Education of the Brazilian Ministry of Education (HHE/BME) (Note 1) should rule these issues through resolutions; however, this has not happened yet. The big question is: How and when will the Ministry of Education or Brazil's Government solve these queries? So far this question remains unanswered.

Thus the course load and the contents to be approached in Libras courses in Higher Education have been designed by each school/college. This way, each institution has its own criteria for designing their courses. In view of that fact, if not randomly established, such criteria either do not exist or are questionably chosen. It should be therefore reflected that the inclusion of Libras course has represented an advance for diffusing that language and, as a consequence, improving the accessibility of the deaf. However, the loopholes in the current laws and the lack of guidelines recommended by HHE/BME still have been an obstacle to adopt and implement a common core curriculum for Higher Education Institutions in Brazil.

\section{An Overview on Linguistic Aspects of Libras}

A large number of studies on sign language linguistics have been conducted worldwide. In addition, addressing linguistic aspects about a sign language in full would require a whole book or a specific thesis. That is why language issues about Libras will be succinctly approached. With this in mind, my theoretical framework will be mostly based on Quadros and Karnopp (2004), Valli, Lucas and Mulrooney (2005), and Gesser (2009).

Based on a generative perspective, it might be asserted that sign languages are equipped with all the features of natural languages. From this perspective, Quadros and Karnopp (2004, p. 30) posit, "Sign languages are considered as natural languages and, as a consequence, they share a number of features which gives to them a specific nature and distinguishes them from the other communication systems [...] Sign languages are thus regarded by Linguistics as natural languages or an authentic language system, and not as a problem of the deaf or a pathology of the language. 
In 1960, Stokoe recognized and confirmed that the sign language met all linguistic criteria of a genuine language, in the lexicon, in the syntax, and in the capability of generating an infinite amount of sentences." (Note 2)

Sign language researchers have ratified that language principles such as arbitrariness, flexibility, versatility, discontinuity, creativeness and productivity, double articulation, structural dependence, which had been formerly related to the oral languages, are also associated with the sign languages. Notwithstanding the gesture-visual modality, "Brazilian Sign Language, used by the Brazilian deaf community that is all over the country, is organized, in a way, as complex as the oral-auditory languages" (Quadros \& Karnopp, 2004, p. 127). Due to that complexity, sign languages might be analyzed in terms of phonology, morphology, syntax, semantics and pragmatics, and discourse.

Regarded as the "father of ASL Linguistics", William Stokoe was the first researcher to analyze the inner grammatical structure of a sign language. By describing phonological and morphological aspects of American Sign Language (ASL), he pointed out three parameters, which are: Handshape (HS); Location (L); and Movement (M). This author observed that signs were not merely made up of images; they were furthermore made up of complex abstract symbols, in which the internal structure was complex as well. Later Battison $(1974,1978)$ observed that the parameters of Palm Orientation and Non-Manual Expressions also belonged to the phonological structure of the signs.

With regard to sign language phonology, it must be understood, "Phonology is the level of grammatical analysis where primitive structural units without meaning are recursively combined to create an infinite number of meaningful utterances. It is the level of grammar that has a direct link with the articulatory and perceptual phonetic systems, either a visual/gestural pair or an auditory/vocal pair of peripheral systems." (Brentari, 1998, p. 1-2) Another concept, which does not belie the previous definition, states that, "Phonology of sign languages is a Linguistics branch that aims at identifying the structure and the organization of the phonological strings so as to propose explanatory and descriptive models.” (Quadros \& Karnopp, 2004, p. 47) Although the term phonology may sound weird when related to the sign languages, especially for a layman or laywoman, many authors have been using it when describing and analyzing the phonological structure of the signs (Stokoe, 1960; Battison, 1974, 1978; Liddell and Johnson, 1986, 1989; Padden and Perlmutter, 1987; Sandler, 1989; van der Hulst, 1989, 1993, 1995a, 1995b; Ferreira-Brito, 1990a, 1995; Karnopp, 1994, 1999; Marentette, 1995; Brentari, 1998; Crasborn, van der Hulst, and van der Kooij, 2000; Xavier, 2006; Bento, 2010).

Still regarding phonology, when proposing an instrument to assess the phonology of Libras, Costa (2012) has found out and described the phonological processes observed in the language acquisition of Brazilian deaf children. For having been influenced by the scholars of ASL Linguistics, and following the prosodic model of sign language phonology as proposed by Brentari (1998), in his thesis, he examined and found out the phonological processes of assimilation, epenthesis, elision, and metathesis. It is not necessary to explain them here, whereas it is appropriate to stress that phonological processes are not unique to the oral languages.

Apart from the fact that there is a level of phonological analysis for the sign languages, it is realized that signs might be split into smaller units that are not "phonemes". These units are smaller than a word and bigger than the "phoneme"; they are referred to as morphemic units. Concerning morphology, Quadros and Karnopp (2004, p. 86) asserts that this field deals with "the study of the internal structure of the words or of the signs, as well as the rules that define the word formation." It is worth mentioning morphological processes are also observed in sign languages. The authors at stake pose that both derivation processes and inflection processes are observed in Libras. In their work, they described the morphological processes which follow: derivation (names from verbs); formation of compounds; number-incorporation; negative-incorporation; and inflection. In addition to the authors quoted above and the others already mentioned, with respect to the researches on Libras morphology, some scholars have investigated and reported relevant findings (Felipe, 2002, 2006; Nascimento and Correia, 2011; Rodero-Takahira, 2012; Finau and Mazzuchetti, 2015; Xavier and Neves, 2016).

Besides phonological and morphological features, concepts and other linguistic phenomena of the semantic field are also noteworthy in sign languages. In this regard, hyponyms, hypernyms, synonyms, antonyms, homonyms, paronyms, among other semantic phenomena could not only have been observed, but also have been analyzed in signed languages. From a semantic perspective, by trying to understand how the deaf individuals construct and deconstruct the processes of metaphoric and polysemic meaning when reading texts in Portuguese, Faria (2003) has observed, in addition to the concepts iconically built, metaphorical and metonymical concepts are also found out in Libras. 
Considering the morphosyntactic features, it might be noticed types of verbs in Libras such as: directional (also referred to as inflected or with agreement) and non-directional (also referred to as non-inflected or with no agreement). There are no especial subtypes for the directional verbs. With respect to non-directional verbs, they are classified as: (i) verbs anchored in the body, and (ii) verbs which incorporate the object(s); these could be also called as classifier verbs. Still with regard to syntactic aspect, it is pertinent to emphasize, "Analyzing a few points about the syntax of a sign language needs to 'view' the system, which is visual/gestural and not oral/auditory." (Quadros \& Karnopp, 2004, p. 127) Although the basic order of the sentence in Libras is S-V-O (i.e., Subject-Verb-Object), the variation in this order is possible depending on the type of the verb or the complexity of the phrase, and, as a result, the sentence is rearranged and the output is grammatically accepted. Moreover, Quadros and Karnopp (2004) also explain how topic and focus phenomena occur in Libras, and because of those findings there is clear evidence that syntactic structures of Libras are as complex as syntactic structures of Portuguese.

Also, sign languages might be linguistically analyzed from a discursive viewpoint. Despite its interdisciplinary nature, we must not, of course, forget that discourse analysis is not a private field of Linguistics. Conversely, from a linguistic approach, it should be understood that, "In sociolinguistics, the term discourse is used to refer to any use of language that goes beyond the sentence. Discourse can refer to how language is organized in conversations, and it can also refer to how the sentences in a written text, such as a novel or a linguistics textbook, are organized. Language has social functions as well as communicative functions, and, therefore, language is a kind of social behavior. The analysis of discourse has a lot to do with the social functions of language." (Valli, Lucas \& Mulrooney, 2005 , p. 169, authors' italics) In light of the foregoing, the importance of discourse analysis for linguistic studies is clear and must not be discarded. Yet there is still a dearth of researches on discourse analysis with respect to sign languages in Brazil; consequently, researches on this field with especial reference to Brazilian sign languages (Note 3) could be a highly promising field.

As stated at the beginning of this section, it is essential to highlight that the purpose of what has been written so far was not to discuss exhaustively the topic about Linguistics of Libras. It is therefore appropriate to scrutinize carefully each one of the authors aforesaid in order to understand thoroughly the levels of linguistic analysis. Finally, it was necessary to point them out succinctly in view of the fact that an overview on the relevant theoretical concepts discussed in the courses of LET E46 and LET E48 was the focus of that section.

\section{Teaching Libras as $\mathrm{L} 2$}

There are a couple of studies discussing or dealing with the topic 'teaching Libras as L2' (Pereira, 2009; Neves, 2011; Albres, 2012; Roa, 2012; Gianotto and Marques, 2014). However, in the current topic, I would like to point out and make assumptions about the convergence and divergence on the concepts of second and foreign languages, as well as discuss the role of the first language in second language teaching. It is important to posit these concerns are very noteworthy, because they are related to my viewpoint concerning the teaching of a second language.

It is a commonplace to draw distinctions between a foreign language (FL) and a second language (L2) in the field of language teaching. As regards Foreign Language Teaching (FLT), the language that is being studied by the student is not the language used outside the classroom environment. As to what concerns Second Language Teaching (SLT), it is expected that learners use the language outside the classroom, given that this language belongs to and is used by that speaking community. Regardless of these definitions, and in the same way as stated by Leffa (1998), the term L2 will be used hereinafter in a sense that embodies the meaning of FL.

On one hand, assuming that Libras is taught as FL in Higher Education, it is expected that students will generally not be inserted into a deaf community, even though the possibility of meeting a deaf person is present. On the other hand, if we consider there is a need (obligatorily or optionally) for the usage of that language in the outer atmosphere of the classroom, we will be able to say students in this case will be learning Libras as L2. Those are the reasons why the term $\mathrm{L} 2$ will be adopted in a broad sense, including both L2/FL conceptions.

In contrast to Libras teaching as L1, professors/teachers of this language as L2 have to adopt specific methods, techniques, strategies and teaching practices. Libras teaching strategies will be approached in the next section. As concerns the teaching of Libras as L1, from the fact that the learner could use his/her native language in the teaching setting, the teacher will thus make use of that language entirely so as to use metalinguistic strategies as well as to foster the development of language skills. As concerns the teaching of Libras as L2, from the fact that the native language of the learner is not the same language used for instruction, the teacher will be able to make use of strategies and techniques aiming at developing communication skills. For this purpose, the use of L1 might be of paramount importance. In accordance with Leffa (2012), it must be emphasized, "Language teaching is also characterized by the duality of language systems, embracing not only the language to be studied but also the L1 of 
the learner, which might play a greater or minor role in the learning of the L2, depending on the concept of learning and language. On the long path of the methods, there were times when the L1 was regarded as a supporting point to be used for learning L2; and other times, it was an obstacle that had to be avoided and forgotten by the student, acting as if it did not exist." (p. 393)

Assuming that L1 may take up a crucial role in the learning of L2, Libras is often used as the language of instruction in case of Portuguese teaching as L2 for the deaf. If it were not so, Portuguese learning would become very complex or would not be so easy to take place. Obviously, for the teaching of Libras as L2 (that is the case of Libras teaching for hearing learners), Portuguese should not be necessarily adopted as the language of instruction. By contrast, this language has to be sometimes used for the purpose of facilitating the learning of Libras, especially at times when deeper explanations are required, depending on the inter-language level of the learner.

It must therefore be understood it is of utmost importance that, in terms of teaching Libras as L2, the sign language should be mostly used for the interaction between teacher and learners in the teaching/learning process. Nevertheless, the use of L1 (i.e., Portuguese), in particular times or for brief explanations, must not be rejected, especially for the students attending basic levels, taking into consideration this language will be able to enhance, optimize, enable and/or empower the learning of Libras as L2.

\section{On the Relevance of the Strategies to Teaching and Learning Libras as L2}

In order that teaching of L2 can be successful, it will be useful to adopt the teaching strategies properly, matching them with the intended purposes. The teacher must foster a couple of strategies to help students learn, but in the end these students will generally develop or find out their own learning strategies. By addressing learning strategies, Gesser (2009, p. 57, author's italics) states, "Our learning is connected with cognitive styles and in general it is not very clear for us the reason why we would rather learn in the way we learn. That is where learning strategies take place. They refer to our choices so-called "conscious", which are the procedures that reflect the processes used by the student to cope with the demands in particular situations. Many learners make use of them, but others need to be reinforced and encouraged."

Seeking to define what is the meaning of strategies, a proper definition is suggested by Nunan (1999). This author asserts, "Strategies are the mental and communicative procedures learners use in order to learn and use the language. Underlying every learning task is at least one strategy. However, in most classrooms, learners are unaware of the strategies underlying the learning tasks in which they are engaged." (p. 171). This author also defends that the greater awareness the learner has of what s/he is doing, the more effective the learning will occur. In this process, the consciousness about the processes underlying the learning is relevant to the student.

Teaching and learning must not be considered independent processes from the fact that they are interdependent. This way, the teaching process is intertwined with the learning process and vice-versa. For these assumptions, many researchers have called it as "teaching-learning process". So the teacher has to be considered as "a learner among other learners" (Nunan, 1999), and the learner now and then may become the facilitator when bringing up to the learning atmosphere both his/her viewpoint and his/her world reading.

A way of optimizing the teaching/learning process is to offer or propose meaningful activities for the student. In this concern, Luckesi (2011) considers, "Exercitation is an act of the pupil, who is active; for this reason, at the time of teaching, the educator must provide to him/her situations in which s/he practices what is being taught with an eye on his/her appropriateness in an effective way." (p. 123). Noticeably, the aim of the proposed activities is not either to transform them into mechanical activities or to become them recurring tasks. By contrast, where there is a need to foster repeated actions for the reinforcement, the aim is to make possible the learning through the "[...] establishment of new neural synapses in the central nervous system of the exerciser under the form of the learner's memory, so that it will be available when its use is needed." (Luckesi, 2011, p. 123)

Based on the strategies described by Oxford, (Note 4) Gesser (2012) suggests, "Each one of these strategies may be explored by the teacher and the student." (p. 60). By suggesting a given activity, the teacher will be able to expect from the student a certain strategy and dissimilarly this student may come up with another strategy. That is, the teacher foresees (and expects) a particular strategy when planning a specific activity, but the strategy to be adopted or used by the student will not be necessarily similar to that one expected.

It is also worth mentioning that Oxford (1990, p. 9) identifies twelve (12) key features of strategies. In this perspective, she states that language learning strategies: (i) contribute to the main goal, communicative competence; (ii) allow learners to become more self-directed; (iii) expand the role of teachers; (iv) are problem-oriented; (v) are specific actions taken by the learner; (vi) involve many actions taken by the learner, not just the cognitive; (vii) 
support learning both directly and indirectly; (viii) are not always observable; (ix) are often conscious; (x) can be taught; (xi) are flexible; and, (xii) are influenced by a variety of factors. For the evaluation tool proposed in this paper, all these strategies have been taken for granted.

For a smooth running of the activities proposed for the subjects of Libras, both teaching and learning strategies have been conducted under the practice of exercises. This way, those exercises have comprehended: several dynamics (for making use of the manual alphabet and the numbers - ordinals and cardinals); gaming activities (for learning the different types of handshapes as well as grasping the different kinds of non-manual expressions); activities for developing conversational skills (for drawing up conversations); activities for fostering the ability to form and understand sentences in Libras; among others. At last, for the classes of Libras as L2, it is important to promote participatory and interactive activities, as well as to foster playful/entertaining activities so as to engender a good atmosphere for learning, despite the compulsory requirement of the subject concerned.

\section{A Proposal for Evaluating the Teaching and Learning Process of Libras}

\subsection{Research Context}

The learning assessment proposal described in the succeeding subsection has been used till then for the courses of LET E46 (Brazilian Sign Language) and LET E48 (Brazilian Sign Language - Level I). Both courses are offered by the Institute of Languages and Arts at the Federal University of Bahia (ILA/FUBa). (Note 5) The main difference between these two courses has to do with the course load: while the workload of LET E46 is 34 hours; the workload of LET E48 is 68 hours. This proposal has been planned and used so far exclusively by the professor who is the author of this paper. It is pertinent to point out that some colleagues from the same institution have become interested in adopting the same proposal.

In order to comply with the provisions of the Decree \# 5626 (cf. Brasil, 2005), which were previously discussed, the ILA/FUBa approved the courses aforesaid in 2009. As of 2011, Libras courses began to be offered to all the undergraduate courses, mandatorily required for the licentiateship degrees, as well as the degrees of Speech and Language Therapy, and Pedagogy, in compliance with the decree mentioned. Initially there were two substitute professors to meet post-decree training demand. Over time there was a need of a tendering procedure. To make a long story short, Table 1 summarizes the amount of the tenured professors who are actually teaching Libras at the institution aforementioned.

Table 1. Professors teaching Libras at the Federal University of Bahia

\begin{tabular}{cccc}
\hline Work type & $\begin{array}{c}\text { Professional position } \\
\text { (Note 6) }\end{array}$ & Workload & Amount \\
\hline Full-time & Professor Assistente & $40 \mathrm{~h}$ & 1 \\
\hline \multirow{2}{*}{ Part-time } & Professor Assistente & $20 \mathrm{~h}$ & 1 \\
& Professores Auxiliares & $40 \mathrm{~h}$ & 3 \\
& & $20 \mathrm{~h}$ & 1 \\
\hline
\end{tabular}

As shown in Table 1, a number of six (6) tenured professors have been teaching Libras courses at FUBa. Of these six professors, two (2) of them are "Professores Assistentes", that is, one professor works full-time, and the other works part-time. The others (4) are "Professores Auxiliares", and all of them work part-time. Concerning these four, while the workload of the one is $20 \mathrm{~h} /$ week, the workload of the three others is $40 \mathrm{~h} /$ week. It is important to mention that for 2017 a tendering procedure is already under way to fill a vacant post for the field of Libras. This vacant post is for a "Professor Auxiliar" in part-time work with the workload of $40 \mathrm{~h} /$ week. As for the students of the classes in which the tenured professor is vacant, one substitute professor had to be hired to meet this demand.

\subsection{Description of the Proposal and a Few Outcomes}

From now on, the tool designed and used to evaluate the performance of the undergraduates will be demonstrated. It will be also explained a few outcomes in the first term of 2017 (2017.1). Additionally certain issues presented in the previous sections will be taken up and discussed where applicable. 
Firstly legal aspects were not taken into consideration for discussing. This way, it is important to underscore that contents to be approached in Libras courses, as well as how these contents should be assessed, have not yet been dealt with in laws, decrees and other legal documents (resolutions and recommendations of HHE/BME). For the reasons stated, it would become impossible for me to conduct a contrasting analysis between that proposal and legal issues.

In Frame 1, it is shown the template used for evaluating one of the practical activities. The goal of this activity was to produce a dialog in Libras, which must be done through working in pairs. Each pair ought to compose the dialog and shoot a video based on one of the following topics: (i) family; (ii) school environment; (iii) work and professions; (iv) food; (v) means of communication; (vi) means of transportation; (vii) clothes/garments; and (viii) sports and leisure activities. These topics were first raffled among the undergraduates; then they were previously made aware of the assessment criteria, which are summarized in the aims that follow:

- For employing greetings, leave-takings and other correlate expressions;

- For using the signs parameters appropriately (handshape, place of articulation, movement, and palm orientation);

- For making use of non-manual expressions;

- For organizing the conversational turns equally;

- For making use of the dactylology (manual alphabet);

- For employing the vocabulary taught in class (nouns, numbers, adjectives, verbs and adverbs);

- For recording the video by framing the participants properly;

- For shooting the video in high-quality resolution;

- For observing presentation time range (no more than four minutes and no less than two minutes and a half);

- For transcribing and handing in a piece of paper containing the script of what was dialoged.

\section{Federal University of Bahia - FUBa}

Institute of Languages and Arts - ILA

Department of Vernacular Languages

Subjects: LET E46 / E48 - Brazilian Sign Language courses

Professor: [temporarily hidden] Date:

Students:

Maximum grade: 5.0

Students' score:

\section{$2^{\text {nd }}$ LIBRAS EVALUATION - PRACTICAL ACTIVITY}

(Period 2017.1)

\section{Rating points:}

1. Use of greetings and leave-takings

\begin{tabular}{|c|l|}
\hline 0.5 & Greetings and leave-takings were coherently used. \\
\hline 0.25 & Greetings and leave-takings were used, but sometimes they were not properly used. \\
\hline 0 & Greetings and leave-takings were not used. \\
\hline
\end{tabular}

2. Use of Non-Manual Expressions (NME) 


\begin{tabular}{|c|l|}
\hline 1.0 & All NME were precisely and coherently used. \\
\hline 0.75 & Most of NME were precisely and coherently used. \\
\hline 0.5 & ENM were not either applied or seemed inappropriate to its context. \\
\hline 0 & ENM were never used. \\
\hline
\end{tabular}

3. Use of the manual alphabet (dactylology) when necessary

\begin{tabular}{|c|l|}
\hline 1.0 & Dactylology was precisely used. \\
\hline 0.5 & Dactylology was not always clear or there was confusion when using one or more handshapes. \\
\hline 0 & Dactylology was not clear and, as consequence, word/s was/were misspelled. \\
\hline
\end{tabular}

4. Use of the verbs/adjectives taught in class

\begin{tabular}{|l|l|}
\hline 1.0 & Adjectives and verbs were acceptably used. \\
\hline 0.7 & Most of them were acceptably used. \\
\hline 0.3 & $\begin{array}{l}\text { They were used, but sometimes they were not right and/or there were a few distortions in the signs } \\
\text { parameters. }\end{array}$ \\
\hline 0 & Verbs and adjectives were never used. \\
\hline
\end{tabular}

5. Use of the vocabulary taught in class, except verbs and adjectives

\begin{tabular}{|c|l|}
\hline 1.0 & The signs concerning the vocabulary taught in class were properly used. \\
\hline 0.5 & The signs taught in class were used but there were a couple of distortions in one or more of them. \\
\hline 0 & The signs taught in class were not used. \\
\hline
\end{tabular}

6. As for the presentation time of the dialog (Minimal: 2 min and 30seg; maximum: 4 min)

\begin{tabular}{|c|l|}
\hline 0.5 & Presentation time has satisfied the scheduled time range. \\
\hline 0.25 & Presentation time was short. \\
\hline 0 & Presentation time was long. \\
\hline
\end{tabular}

Frame 1. A template for evaluating a practical activity: "producing a dialog in Libras" (pair work)

By taking a look at Frame 1 quickly, it might seem that linguistic aspects have only been measured on a normative perspective, but this is not true. Even though it does not seem so explicit for the reader, it is important to emphasize, when using the adverbs coherently, properly, precisely, acceptably, and so forth, it is embedded in them the evaluation of phonology, morphology and syntax aspects. By saying confusion or distortion in the sign parameters, I am most importantly looking at phonology and morphology characteristics. Also, when assessing language issues, I take into account the proficiency level of the learners rather than decreasing students' score for very minor errors.

The template exposed in Frame 1 has been used to evaluate students' production appropriately. It is convenient to highlight that they should shoot a high-resolution video in order to ensure high quality images for assessment purposes. Additionally, the relevance of handing in a piece of paper containing the dialog script along with the video recording has been related to a fair valuation, because, if observed an uncertainty in one or more signs, it/they might be settled by taking a look at what was written in the script. Eventually, students set forth some signs which were not 
clear or precise. If those signs have already been taught in class, they should have been measured as confused and distorted signs; otherwise, they should have been appreciated as right for not having been taught in class before.

On the deadline destined to hand in the video recording, students must first do a self-evaluation by using the same guidelines shown in Frame 1. After doing so, they handed in the video recording, the dialog script and the form containing the self-evaluation. In addition to being a good strategy for SLT, self-evaluation strategies may help students develop criticizing capabilities. It seems to me that, about the learning strategies adopted or developed during Libras courses, students achieve many (if not all) of the language learning strategies as described by Oxford (1990). However, a specific research on these strategies is still mandatory to investigate particularly this subject.

Table 2. Total amount of students per class in the first term of 2017

\begin{tabular}{|c|c|c|c|c|c|c|}
\hline \multirow[t]{2}{*}{ Groups } & \multirow{2}{*}{$\begin{array}{c}\text { LET E48 } \\
\text { Group } 8\end{array}$} & \multirow{2}{*}{$\begin{array}{c}\text { LET E46 } \\
\text { Group } 3\end{array}$} & \multirow{2}{*}{$\begin{array}{c}\text { LET E46 } \\
\text { Group } 5\end{array}$} & \multirow{2}{*}{$\begin{array}{c}\text { LET E46 } \\
\text { Group } 6\end{array}$} & \multicolumn{2}{|c|}{ Total } \\
\hline & & & & & Absolute & Percentage \\
\hline Approved & 27 & 20 & 17 & 23 & 87 & $69,6 \%$ \\
\hline Failure & 0 & 0 & 0 & 0 & 0 & $0 \%$ \\
\hline $\begin{array}{c}\text { Failure for } \\
\text { non-attendance }\end{array}$ & 3 & 6 & 7 & 5 & 21 & $16,8 \%$ \\
\hline $\begin{array}{c}\text { Leave of } \\
\text { Absence (LOA) }\end{array}$ & 1 & 4 & 5 & 7 & 17 & $13,6 \%$ \\
\hline $\begin{array}{c}\text { Total } \\
(\%)\end{array}$ & $\begin{array}{c}31 \\
(24,8 \%)\end{array}$ & $\begin{array}{c}30 \\
(24 \%)\end{array}$ & $\begin{array}{c}29 \\
(23,2 \%)\end{array}$ & $\begin{array}{c}35 \\
(28 \%)\end{array}$ & 125 & $100 \%$ \\
\hline
\end{tabular}

As shown in Table 2, a total of a hundred and twenty-five (125) students were enrolled in the courses of the professor under analysis. These students were located at the following groups/classes: thirty-one $(31 ; 24,8 \%)$ students were enrolled in the classes in the group 8 of LET E48; thirty $(30 ; 24 \%)$ students were enrolled in the classes in the group 3 of LET E46; twenty-nine $(29 ; 23,2 \%)$ students were enrolled in the classes in the group 5 of LET E46; and thirty-five $(35 ; 28 \%)$ students were enrolled in the classes in the group 6 of LET E46. As regards the status, eighty-seven students $(69,6 \%)$ concluded successfully one of the courses; twenty-one students $(16,8 \%)$ did not pass for having been reproved due to non-attendance; and seventeen students $(13,6 \%)$ were granted a leave of absence (LOA) before ending the semester. It is appropriate to point out that there was not any student reproved for failure. Also, it is pertinent to stress that students enrolled in the courses of the other professors were not taken into consideration for they were not submitted to the same procedure of evaluation.

Table 3. Students' outcomes (results of the practical activity) in the first half of 2017

\begin{tabular}{ccccccccc}
\hline & \multicolumn{2}{c}{ LET E48 $($ G8) } & \multicolumn{2}{c}{ LET E46 (G3) } & \multicolumn{2}{c}{ LET E46 (G5) } & \multicolumn{2}{c}{ LET E46 (G6) } \\
\cline { 2 - 9 } & $\mathbf{n = 3 1}$ & $\mathbf{n = 2 7}$ & $\mathbf{n = 3 0}$ & $\mathbf{n = 2 0}$ & $\mathbf{n = 2 9}$ & $\mathbf{n = 1 7}$ & $\mathbf{n = 3 5}$ & $\mathbf{n = 2 3}$ \\
\hline Average & 3.53 & 4.07 & 3.12 & 4,37 & 2.10 & 3,16 & 2.76 & 4,14 \\
Median & 4.0 & 4.0 & 4.0 & 4,6 & 2.5 & 3,4 & 3.7 & 4,2 \\
\hline
\end{tabular}

Largely the students have reached good scores in Libras courses. In Table 3, the results were exhibited as follows: (1) at the first column of each group, the outcomes refer to the total amount of students per class; and, (2) at the second column of each group, the outcomes refer to the students excepting those ones who either requested a LOA or were reproved for non-attendance. By extracting from each group the students that were not approved in the courses, both averages and medians have increased meaningfully, except to the medians of G8 - LET E48 which have kept constant. The general results ( $\mathrm{G} 8-\mathrm{n}=31 ; \mathrm{G} 3-\mathrm{n}=30$; G5 $-\mathrm{n}=29 ; \mathrm{G} 6-\mathrm{n}=35$ ) were not so important for the analysis due to the fact that these outcomes must have been certainly distorted by the presence of students who did not make the examination. So the most relevant data are those ones related to the students who had attended greater than or equal to $75 \%$ of the classes, and, as a consequence, they performed quite well as shown at G8 $-\mathrm{n}=27$; $\mathrm{G} 3-\mathrm{n}=20$; $\mathrm{G} 5-\mathrm{n}=17 ; \mathrm{G} 6-\mathrm{n}=23$. 
Definitely, the tool described in the paragraphs above has not only optimized correction process for the professor, but it has also eased the professor's feedback process to the learners. In spite of having been used other tools to evaluate students' performance, it was not pertinent to demonstrate them from the fact that their goal has to do with the evaluation of theoretical issues. It is worth mentioning that the focus of this paper was to demonstrate the tool designed to assess the main practical activity. Furthermore, the instrument proposed surpassed expectations in terms of assessing students' production in Libras courses; that is, in addition to assessing students' performance objectively, carefully and precisely, it also served as a baseline to judge and review teaching practices.

\section{A Few Ending Remarks}

When proposing in this paper a tool for evaluating the learning process of Brazilian Sign Language as L2 within the context of Higher Education, I theorized relevant issues intertwined with the proposal. Accordingly, Brazilian laws, Linguistics of Libras, Libras teaching as L2, as well as teaching and learning strategies, were discussed. Taking into consideration that planning proper tools for assessment purposes is a must for teachers committed to teaching/learning process, I would like to close with the words of Luckesi (2011, p. 376) who states, "A well-designed tool is the prerequisite for the satisfactory completion of both evaluating and examining acts. It is a resource that expands our observational ability, doing justice to the reality with which we work. By acting as evaluators or as examiners, we might not give up on that process."

Definitively, I have drawn to a close that formulating objective tools for the assessment of student in teacher training courses is of paramount importance. In addition to facilitating and optimizing the evaluation process for the educator, the learners will be able to see clearly how all the criteria set out for assessment purposes are elucidative and transparent. Thus developing tools as well as presenting proposals for sign languages teaching might be ways to highlight and discuss pedagogical issues on the teaching of those languages.

Although this study has been conducted in and limited to a single higher education institution, the findings might have an impact on the fields of teacher training for deaf education and sign language research. Nevertheless, the evaluation proposal described in the previous section must be applied to other classes and contexts in order to ratify or rectify those findings and in addition further research is needed to validate the tool proposed. It is also worth mentioning that there is a shortage of literature concerning methods and techniques for Libras teaching as L2. This way, the significance of the current study dwells on providing more content to the existing body of knowledge with regard to the teaching and learning processes of Libras as L2.

\section{References}

Albres, N. A. (2012). Ensino de Libras como segunda língua e as formas de registrar uma língua visuo-gestual: problematizando a questão. ReVEL, 10(19), 125-149. Retrieved from http://www.revel.inf.br/files/6e9e138e1df0292c48e355324465cb64.pdf

Battison, R. (1974). Phonological deletion in American Sign Language. Sign Language Studies, 5, 1-19. https://doi.org/10.1353/sls.1974.0005

Battison, R. (1978). Lexical borrowing in American Sign Language. Silver Spring, MD: Linstok.

Bento, N. A. (2010). Os parâmetros fonológicos: configuração de mãos, ponto de articulação e movimento na aquisição da língua brasileira de sinais - um estudo de caso (Master Thesis). Salvador, BA: Universidade Federal da Bahia. Retrieved from https://repositorio.ufba.br/ri/handle/ri/8409

Brasil. (2000). Lei n. 10.098, de 19 de dezembro de 2000. Estabelece normas gerais e critérios básicos para a promoção da acessibilidade das pessoas portadoras de deficiência ou com mobilidade reduzida, e dá outras providências. Retrieved from http://www.planalto.gov.br/ccivil_03/leis/L10098.htm

Brasil. (2002). Lei n. 10.436, de 24 de abril de 2002. Dispõe sobre a Língua Brasileira de Sinais - Libras e dá outras providências. Retrieved from http://www.planalto.gov.br/ccivil_03/leis/2002/110436.htm.

Brasil. (2005). Decreto n. 5.626, de 22 de dezembro de 2005. Regulamenta a Lei ${ }^{\circ} 10.436$, de 24 de abril de 2002, que dispõe sobre a Língua Brasileira de Sinais - Libras, e o art. 18 da Lei n ${ }^{\circ} 10.098$, de 19 de dezembro de 2000. Retrieved from http://www.planalto.gov.br/ccivil_03/_ato2004-2006/2005/decreto/d5626.htm

Brentari, D. (1998). A prosodic model of sign language phonology. Cambridge: MIT Press.

Costa, R. C. R. (2012). Proposta de instrumento para a avaliação fonológica da língua brasileira de sinais: FONOLIBRAS (Master Thesis). Salvador, BA: Universidade Federal da Bahia. Retrieved from https://repositorio.ufba.br/ri/handle/ri/17216 
Crasborn, O., Hulst, H. van der, \& Kooij, E. van der. (2000, January 28). Phonetic and phonological distinctions in sign languages. Intersign Introduction Chapter (draft). Retrieved from http://www.sign-lang.uni-hamburg.de/intersign/internal/vdhulst2.pdf

Damasceno, L. S. M. (2017). Surdos Pataxó: inventário das línguas de sinais em território etnoeducacional (Master Thesis). Salvador, BA: Universidade Federal da Bahia.

Faria, S. P. (2003). A metáfora na LSB e a construção dos sentidos no desenvolvimento da competência comunicativa de alunos surdos (Master Thesis). Brasília, DF: Universidade de Brasília. Retrieved from http://repositorio.unb.br/handle/10482/5287

Felipe, T. A. (2002). Sistema de Flexão Verbal na LIBRAS: Os classificadores enquanto marcadores de flexão de gênero. In Anais do Congresso Surdez e Pós-Modernidade: Novos rumos para a educação brasileira (p. 37-58). $1^{\circ}$ Congresso Internacional do INES \& $7^{\circ}$ Seminário Nacional do INES. Rio de Janeiro: INES, Divisão de estudos e Pesquisas.

Felipe, T. A. (2006). Os processos de formação de palavra na Libras. ETD - Educação Temática Digital 7, 2 , 200-217. Retrieved from https://periodicos.sbu.unicamp.br/ojs/index.php/etd/article/view/803

Ferreira-Brito, L. (1984). L. Similarities and differences in two sign languages. Sign Language Studies, 42, 45-46. Silver Spring: Linstok Press. https://doi.org/10.1353/sls.1984.0003

Ferreira-Brito, L. (1990a). Uma abordagem fonológica dos sinais da LSCB. Espaço: Informativo técnico-científico do INES, 1(1), 20-43.

Ferreira-Brito, L. (1990b). Epistemic, alethic, and deontic modalities in a Brazilian Sign Language. In S. D. Fisher, \& P. Siple (Eds.), Theoretical issues in sign language research (v. 1). University of Chicago Press.

Ferreira-Brito, L. (1995). Por uma gramática de línguas de sinais. Rio de Janeiro, RJ: Tempo Brasileiro.

Finau, R. A., \& Mazzuchetti, V. (2015). A incorporação de numeral em estruturas classificadoras de Língua Brasileira de Sinais. ReVEL, 13(24), 67-86.

Gesser, A. (2009). Libras? Que língua é essa?: crenças e preconceitos em torno da língua de sinais e da realidade surda. São Paulo, SP: Parábola Editorial.

Gesser, A. (2012). O ouvinte e a surdez: sobre ensinar e aprender Libras. São Paulo, SP: Parábola Editorial.

Gianotto, A. O., \& Marques, H. R. (2014). Ensino de Língua Brasileira de Sinais (LIBRAS) como segunda língua para falantes da Língua Portuguesa. Multitemas, 46, 125-137. Retrieved from http://www.multitemas.ucdb.br/article/viewFile/177/217

Hulst, H. van der. (1989). Atoms of segmental structures: components, gestures and dependency. Phonology, 6(2), 253-284. https://doi.org/10.1017/S0952675700001020

Hulst, H. van der. (1993). Units in the analysis of signs. Phonology, 10(2), 209-241. https://doi.org/10.1017/S095267570000004X

Hulst, H. van der. (1995a). Head-dependency relations in the representation of signs. In H. Bos, \& T. Schermer (Eds.), Sign language research 1994: Proceedings of the 4th European congress on Sign language research. Münich 1-3 September 1994. Hamburg: Signum Press. 11-38. Retrieved from http://linguistics.uconn.edu/pdf/Harry/NEW/066-Head-dep relations in signs.pdf

Hulst, H. van der. (1995b). The composition of handshapes. Trondheim Working Papers, 23, 1-17. Retrieved from http://harry-van-der-hulst.uconn.edu/wp-content/uploads/sites/1733/2016/05/067-The-Composition-of-Handsha pes.pdf

Karnopp, L. B. (1994). Aquisição do parâmetro configuração de mão dos sinais da LIBRAS: estudo sobre quatro crianças surdas filhas de pais surdos (Master Thesis). Porto Alegre, RS: Pontifícia Universidade Católica do Rio Grande do Sul.

Karnopp, L. B. (1999). Aquisição fonológica na língua brasileira de sinais: estudo longitudinal de uma criança surda (PhD Dissertation). Porto Alegre, RS: Pontifícia Universidade Católica do Rio Grande do Sul. Retrieved from http://hdl.handle.net/10183/60505

Leffa, V. J. (1988). Metodologia do ensino de línguas. In H. I. Bohn, \& P. Vandresen (Eds.), Tópicos em linguística aplicada: o ensino de línguas estrangeiras (pp. 211-236). Florianópolis, SC: Editora da UFSC. Retrieved from http://www.leffa.pro.br/textos/trabalhos/Metodologia_ensino_linguas.pdf 
Leffa, V. J. (2012). Ensino de línguas: passado, presente e futuro. Revista de estudos da linguagem, 20(2), 389-411. https://doi.org/10.17851/2237-2083.20.2.389-411

Liddell, S. K., \& Johnson, R. E. (1986). American Sign Language compound formation processes, lexicalization, and phonological remnants. Natural language and linguistic theory, 4, 445-513. https://doi.org/10.1007/BF00134470

Liddell, S. K., \& Johnson, R. E. (1989). American Sign Language: The Phonological Base. Sign Language Studies, 64, 195-277. https://doi.org/10.1353/sls.1989.0027

Luckesi, C. C. (2011). Avaliação da aprendizagem: componente do ato pedagógico (1st ed 5th reprint). São Paulo, SP: Cortez.

Marentette, P. F. (1995). It's in her hands: a case study of the emergence of phonology (PhD Thesis). McGill University, Department of Psychology, Montreal. Retrieved from http://digitool.library.mcgill.ca/webclient/StreamGate?folder_id=0\&dvs=1508383012161 592

Nascimento, S., \& Correia, M. (2011). Um olhar sobre a morfologia dos gestos. Porto: Universidade Católica Editora.

Neves, S. L. G. (2011). Um estudo dos recursos didáticos nas aulas de Língua Brasileira de Sinais para ouvintes (Master Thesis). Piracicaba, SP: Universidade Metodista de Piracicaba. Retrieved from https://www.unimep.br/phpg/bibdig/aluno/visualiza.php?cod=695

Nunan D. (1999). Second Language Teaching \& Learning. Boston, MA, Heinle \& Heinle.

Oxford, R. L. (1990). Language learning strategies: What every teacher should know. New York, NY: Newbury House.

Padden, C., \& Perlmutter, D. (1987). American sign language and the architecture of phonological theory. Natural language \& linguistic theory, 5, 335-375. https://doi.org/10.1007/BF00134553

Pereira, M. C. P. (2009). A Língua de Sinais Brasileira: análise de material didático de ensino como segunda língua para ouvintes. Linguasagem, 1(7). http://www.letras.ufscar.br/linguasagem/edicao07/Artigo_Pereira.php

Quadros, R. M., \& Karnopp, L. B. (2004). Língua de sinais brasileira: estudos linguísticos. Porto Alegre, RS: Artmed.

Roa, M. C. I. (2012). Libras como segunda língua para crianças ouvintes: avaliação de uma proposta educacional (Master Thesis). São Paulo, SP: Universidade Federal de São Paulo. Retrieved from http://www2.unifesp.br/centros/cedess/mestrado/teses/tese_96_como_segunda_lingua_para_criancas_ouvintes_ avaliacao_de_uma_proposta_eduacacional.pdf

Rodero-Takahira, A. G. (2012). Questões sobre compostos e morfologia da Libras. Estudos Linguísticos, 41(1), 262-276. https://revistas.gel.org.br/estudos-linguisticos/article/view/1231

Sandler, W. (1989). Phonological representation of the sign: linearity and non-linearity in American Sign Language. Dordrecht: Foris. https://doi.org/10.1515/9783110250473

Santos, L. F., \& Campos, M. L. I. L. (2014). O ensino de Libras para futuros professores da educação básica. In C. B. F. Lacerda, \& L. F. Santos (Eds.), Tenho um aluno surdo, e agora?: Introdução à Libras e educação de surdos (pp. 237-250). São Carlos, SP: EdUFSCar.

Stokoe, W. C. (1960). Sign language structure: an outline of the visual communication systems of the American Deaf. New York, NY: University of Buffalo Press.

Sumaio, P. A. (2014). Sinalizando com os Terena: um estudo do uso da Libras e de sinais nativos por indígenas surdos (Master Thesis). Araraquara, SP: Universidade Estadual Paulista. Retrieved from https://repositorio.unesp.br/handle/11449/115690

Valli, C., Lucas, C., \& Mulrooney, K. J. (2005). Linguistics of American Sign Language: an introduction. Washington, DC: Gallaudet University Press.

Vilhalva, S. (2009). Mapeamento das línguas de sinais emergentes: um estudo sobre as comunidades linguísticas Indígenas de Mato Grosso do Sul (Master Thesis). Florianópolis, SC: Universidade Federal de Santa Catarina. Retrieved from https://repositorio.ufsc.br/handle/123456789/92972 
Vilhalva, S. (2012). Índios surdos: mapeamento das línguas de sinais do Mato Grosso do Sul. Petrópolis, RJ: Arara Azul.

Xavier, A. N. (2006). Descrição fonético-fonológica dos sinais da língua de sinais brasileira (Libras) (Master Thesis). São Paulo, SP: Universidade de São Paulo.

Xavier, A. N., \& Neves, S. L. G. (2016, jul./dez.). Descrição dos aspectos morfológicos da Libras. Revista Sinalizar, l(2), 130-151. https://doi.org/10.5216/rs.v1i2.43933

\section{Notes}

Note 1. The name of the institution translated into English refers to Câmara de Educação Superior do Ministério da Educação (CES/MEC).

Note 2. From now on, it is pertinent to point out that I myself translated all Portuguese authors used in this paper into English.

Note 3. When using the expression "Brazilian sign languages", it is embedded not only Libras, but also other sign languages that are part of Brazilian deaf communities. In this regard, I would like to mention some of them as follows: Urubu-Kaapor Sign Language (Ferreira-Brito, 1984; 1995); Terena Sign Language (Sumaio, 2014); Pataxó Sign Language (Damasceno, 2017), among others. Additionally, it is pertinent to mention that Vilhalva (2009; 2012) conducted a study in which she mapped the sign languages of indigenous deaf communities in the state of Mato Grosso do Sul, Brazil. However, mapping other sign languages is still required. Lastly, it is worth mentioning we still cannot count on language policies for all deaf communities, in particular indigenous deaf communities in Brazil.

Note 4. By categorizing learning strategies, Oxford (1990) classifies them as the ones which follow: (1) memory strategies (for helping students remember and retrieve new information); (2) cognitive strategies (for empowering learners to understand and produce language); (3) compensation strategies (for allowing students to use language and communicate with one another despite their knowledge 'impairments'); (4) metacognitive strategies (for enabling learners to control their own learning process by planning, coordinating and assessing); (5) affective strategies (for helping students gain control of their emotions, attitudes, motivations and values); and, (6) social strategies (for helping students learn though interaction with other persons). Memory, cognitive and compensation strategies are labeled as direct, and metacognitive, affective and social strategies are labeled as indirect.

Note 5. The term described as ILA/FUBa refers to ILUFBA, which means "Instituto de Letras da Universidade Federal da Bahia".

Note 6. The terms used in Table 1 were not translated into English, once due to non-equivalence between Portuguese and English most of them did not have a one-to-one equivalence. Because of that, the terms for each subtype were kept in Portuguese. It is necessary to explain that in Brazil the terms which describe the teaching career are the following ones: Professor Titular (equivalent to 'Full Professor'); Professor Associado (equivalent to 'Associate Professor' and s/he must hold a PhD); Professor Adjunto (equivalent to 'Assistant Professor' and s/he must hold a $\mathrm{PhD}$ ); Professor Assistente (there is no equivalence even tough some Brazilians usually mention it as "Assistant Professor"; s/he must hold a master's degree); Professor Auxiliar (there is also no equivalence for this one; s/he must hold an undergraduate degree or specialization title). In addition to these categories, there are two others: Professor Substituto (a professor with a short-term contract for replacing professors and other kinds of temporary situations) and Professor Visitante (equivalent to 'Visiting Professor'; s/he holds a $\mathrm{PhD}$ and usually has an obligation of conducting research as described in the temporary contract). 